\title{
CONTRIBUTION TO THE STUDY OF Himatanthus sucuuba: LATEX MACROMOLECULE, MICROELEMENTS AND CARBOHYDRATES
}

Jefferson Rocha de A. SILVA ${ }^{1,4,}$; Ana Claudia F. AMARAL ${ }^{2}$; Antonio C. SIANI ${ }^{2}$; Claudia M. REZENDE ${ }^{4}$; Judith FELCMAN ${ }^{3}$; Angelo C. PINTO ${ }^{4}$

ABSTRACT: The polymeric material in the latex of Himatanthus sucuuba (Spruce) Woodson was identified by spectroscopic methods as cis-polyisoprene $\left(M_{n}=192 ; M_{W}=571 ; M_{W}\right.$ ' $\left.\mathrm{M}_{\mathrm{n}}=2.97\right)$. ICP-MS analysis of microelements in the aqueous phase showed the most abundant to be $\mathrm{Ca}(354 \mu \mathrm{g} / \mathrm{g})$ and $\mathrm{Mg}(250 \mu \mathrm{g} / \mathrm{g})$. Carbohydrate analysis of the aqueous phase by HPLC-PAD showed arabinose, glucose, xylose, rhamnose and galactose to be the predominant saccharides.

KEYWORDS: Apocynaceae, Himatanthus, latex, cis-polyisoprene, microelements, carbohydrates

\section{CONTRIBUIÇÃO AO ESTUDO DE Himatanthus sucuuba: MACROMOLÉCULA, MICROELEMENTOSE CARBOIDRATOS DO LÁTEX}

RESUMO : O polímero do látex de Himatanthus sucuuba (Spruce) Woodson foi identificado por métodos espectroscópicos como o cis-poliisopreno $\left(\mathrm{M}_{\mathrm{n}}=192 ; \mathrm{M}_{\mathrm{w}}=571 ; \mathrm{M}_{\mathrm{w}} / \mathrm{M}_{\mathrm{n}}=2.97\right)$. A análise de microelementos na fase aquosa por ICP-MS forneceu Ca (354 mg/g) e Mg (259 $\mathrm{mg} / \mathrm{g}$ ) como elementos majoritários. A detecção de carboidratos na fase aquosa por CLAEDPA apresentou arabinose, glucose, xilose, ramnose e galactose como açúcares principais.

PALAVRAS-CHAVE: Apocynaceae, Himatanthus, látex, cis-poliisopreno, microelementos, carboidratos

\footnotetext{
1," Departamento de Quírica - Universidade do Amazonas - Campus Universitário-Mini-Campus -Av. Gal. Rodrigo Otávio JordãoRamos, 3000-Japiim-Mknaus - AM, 69077-000, Brazil e-mail: rocha31ahotmail.com.

${ }^{2}$ Far-Manguinhos-FTOCRUZ - Rua Sizenando Nabuco, 100 - Manguinhos - RJ, 21041-250.

${ }^{3}$ Pontifícia Universidede Católica do Rio de Janeiro, Departamento de Química, RuaMrarques de São Vicente, 225 - Griea $-\mathrm{RJ} ; 22453-900$.

${ }^{4}$ Instituto deQứnica - Universidede Federal do Riode Janeiro - CidadeUniversitária - Tlha do FundëoC.T., Bl. A - Riode Janeiro-RJ, 21945-970.
} 


\section{INTRODUCTION}

\section{Himatanthus sucuuba (Spruce)}

Woodson (Apocynaceae) is a medium-sized tree growing on firm ground in the Amazon region, popularly known as sucuuba, sucuba or janaguba. Its wood is used for construction and other purposes. The trunk bark is popularly used for the treatment of gastritis, stomach ulcers and hemorrhoids (van den Berg, 1984), and as an analgesic (Elisabetsky et al., 1990). In the Peruvian Amazon it is reportedly used for hernias, boils and tumors (Perdue et al., 1978).

The latex, a bark exudate, is used in natura as an antihelmintic (Corrêa, 1975), antitumor, antifungal and antiphlogistic (van den Berg, 1984) agent, as well as for poultices and fractures. Chemical studies have indicated the presence of the iridoids fulvoplumierin, plumericin and isoplumericin, which possess antifungal, antibiotic (Vilegas et al., 1992) and cytotoxic (Hamburger et al., 1991) activities. Fractionation of the bark extract, guided by antifungal bioassay, demonstrated strong activity against Cladosporium sphaerospermum (Silva et al., 1998). Antiphlogistic and analgesic activities were also detected in in vivo tests, and associated with the presence of cinnamoyl esters of hydroxytriterpenes in the latex (Miranda et al., 2000).

Several functions have been attributed to latexes and resins, including transport and storage of nutrients, regulation of water-balance, the capacity to store non-functional products of secondary metabolism and protection against pathogens. The occurrence of isoprenoid substances in latexes is already well established in the plant families Euphorbiaceae, Moraceae, Asclepiadaceae, Compositae, Guttiferae and Apocynaceae (Tanaka, 1989).
Hevea brasiliensis latex, for example, contains 30 to $40 \%(\mathrm{w} / \mathrm{v})$ of isoprenoid material, and about $5 \%(\mathrm{w} / \mathrm{v})$ of nonisoprenoid substances in its composition. The latter are dissolved or suspended in the aqueous medium, or are adsorbed on the surface of the rubber (Tanaka, 1989). The non-polymeric material consists mainly of minerals, lipids, terpenes, proteins, carbohydrates and amino acids (Aik-Hwee et al., 1993; Moir, 1959).

The objectives of this report were to determine microelement and carbohydrate composition and characterize the polyisoprene in the latex of Himatanthus sucuuba.

\section{EXPERIMENTAL}

Himatanthus sucuuba latex was collected within the city limits of Santarém, State of Pará, by $\mathrm{Mr}$. Raimundo S. Carneiro. A voucher specimen was deposited at the Herbarium of the Institute of Biological Sciences of the University of Amazonas, Manaus, Brazil, registered under the number 5436 .

The $\mathrm{pH}$ measurement of the crude latex was made digitally (Hanna model 8417), calibrated with potassium hydrogen phthalate $0.05 \mathrm{M}(\mathrm{pH} 4.01)$ and $\mathrm{KH}_{2} \mathrm{PO}_{4} 0.025 \mathrm{M}+$ $\mathrm{Na}_{2} \mathrm{HPO}_{4} 0.025 \mathrm{M}(\mathrm{pH} 6.86)$ buffer solutions.

For the determination of metals, an aliquot of the latex in natura was freeze dried, submitted to acid digestion as described by Pereira et al. (1998), and analyzed by mass spectrometry with inductively coupled Plasma mass spectrometry (ICP-MS), using a PerkinElmer Sciex, model Elan 5000 A instrument, with semi-quantitative calibration and internal standard containing the elements $\mathrm{Li}, \mathrm{Mg}, \mathrm{Na}$, P, K, Ca, Sc, Ti, V, Cr, Mn, Fe, Co, Ni, Cu, Zn, $\mathrm{Ga}, \mathrm{Al}, \mathrm{Zr}$, Th, Si, Sr, Mo, Ag, Cd, Ba, Tl, and $\mathrm{Pb}$. The analysis was made in duplicate. 
${ }^{1} \mathrm{H}$ and ${ }^{13} \mathrm{C}$ NMR spectra were registered on a Bruker AM-200 spectrometer (200 and 50 $\mathrm{MHz}$, respectively), using $\mathrm{CDCl}_{3}$ as solvent and tetramethysilane (TMS) as internal reference. Chemical shifts are expressed in ppm.

Samples were prepared as $\mathrm{KBr}$ pellets and their IR spectra obtained with a Nicolet spectrophotometer with Fourier transform Model Magna-IR 760. Wavelengths are expressed in reciprocal centimeters $\left(\mathrm{cm}^{-1}\right)$.

Gel permeation chromatography (GPC) was carried out with a Waters 600E apparatus using tetrahydrofuran (THF) as mobile phase; flow rate $1 \mathrm{ml} / \mathrm{min}$, and a Waters styragel column with porosity of $500 \AA$. Polystyrene standards used in the calibration curve were: A-500 (500 Da); A-1000 (950 Da); A-8 (2900 Da); A-7 (3600 Da); F-1 (9700 Da); A-5 (33000 Da); A4 (111000 Da); A-3 (200000 Da); A-2 (465660 $\mathrm{Da})$. Refractive Index and ultraviolet (200-400 nm) detectors (Waters Models 410 and 991, respectively) were used.

High performance liquid chromatography, coupled to a pulsed amperometric detector (HPLC/PAD), was performed using a DIONEX Model DX-300 equipped with CarboPac PA-1 anionic exchange column.

$n$-Butanol was added to latex to coagulate the polyisoprene. This mixture was filtered and the filtrate was subjected to liquid-liquid extraction $\left(n-\mathrm{BuOH} / \mathrm{H}_{2} \mathrm{O}\right)$. The aqueous fraction was analyzed by the sulfuric acid - phenol method (Dubois et al., 1956) and by HPLC, as described above (Corradini et al., 1998), for quantification of total sugars.

The polymer obtained was submitted to Soxhlet extraction with acetone and then methanol, and then further purified by selective precipitation from hexane/isopropanol, which yielded $0.61 \%$ of solid material. After this the polymer was re-suspended in THF and submitted to GPC on a styragel column, calibrated with polystyrene standards.

\section{RESULTS AND DISCUSSION}

Analysis of $H$. sucuuba latex by ICP MS showed the presence of several elements. The most abundant were calcium $(354 \mu \mathrm{g} / \mathrm{g})$ and magnesium $(250 \mu \mathrm{g} / \mathrm{g})$. Polyisoprene isolated from the latex was characterized by spectroscopic methods $\left({ }^{1} \mathrm{H}\right.$ and ${ }^{13} \mathrm{C}$ NMR; IR) as being cis-polyisoprene. Analysis by HPLC-PAD of the aqueous fraction indicated the presence of the carbohydrates arabinose, glucose, xylose rhamnose and galactose.

\section{Physico-chemical aspects of $H$. sucuuba latex}

The latex consists of a suspension of particles with $\mathrm{pH} 4.54$, brown coloration and bitter flavor. ICP-MS analysis showed the presence of several microelements (Table 1) of which the most concentrated are related to several therapeutic properties, including the treatment of inflammatory processes and neoplasias (Larson, 1995).

Table 1: Microelements from the latex of $H$. sucuuba

\begin{tabular}{lllllllllll}
\hline Elements & $\mathrm{Na}$ & $\mathrm{Al}$ & $\mathrm{Ca}$ & $\mathrm{Fe}$ & $\mathrm{Ti}$ & $\mathrm{Cr}$ & $\mathrm{Ni}$ & $\mathrm{Zn}$ & $\mathrm{Zr}$ & $\mathrm{Pb}$ \\
\hline Conc. $(\mathrm{mg} / \mathrm{g})$ & 70.5 & 3.88 & 354 & 4.45 & 1.03 & 0.04 & 0.04 & $<0.01$ & 0.35 & 0.08 \\
\hline Elements & $\mathrm{Mg}$ & $\mathrm{K}$ & $\mathrm{Mn}$ & $\mathrm{Sr}$ & $\mathrm{V}$ & $\mathrm{Co}$ & $\mathrm{Cu}$ & $\mathrm{Ba}$ & $\mathrm{Th}$ & \\
\hline Conc. $(\mathrm{mg} / \mathrm{g})$ & 250 & 123 & 8.88 & 3.90 & $<0.001<0.01$ & 0.08 & 0.26 & 0.03 & \\
\hline
\end{tabular}


Calcium and magnesium are very important minerals to life in general. In laboratory animals, increased calcium intake suppresses hyperproliferation of the cells of the colon and, in humans, the ingestion of calcium supplements reduces hyperplasia of colon cells (Lipkin et al., 1995). In humans magnesium participates in important biological functions, promoting good immune defense and taking part in enzymatic reactions. It is indicated for the treatment of stress and for nervous diseases in general, including all well known forms of epilepsy, besides exhibiting anti-allergic, antiphlogistic and analgesic properties. The magnesium ion is indispensable in RNA and DNA synthesis, is important in the prevention of disturbances of the digestive system and also in general of malignant diseases (Wood et al., 1995).

On the other hand, the trace elements, especially manganese, iron, copper and zinc, which are also important to the pharmacological properties of this plant (Silva, 1997), were present in much lower quantity in the latex than in the bark (Silva, 1997). They were also lower in $H$. sucuuba than in other medicinal plants with healing properties (Pereira et al., 1998).

The analysis of sugars revealed a significant amount $(1.9 \mathrm{mg} / \mathrm{ml})$ of total sugars in the crude latex, consisting of arabinose (37.4 $\%)$, glucose (20\%), xylose (9.2\%), rhamnose $(8.4 \%)$ and galactose $(7.4 \%)$. The first two are involved in a series of life maintenance functions, serving, for example, as a plant nutrient reserve during growth and development (Agrawal, 1992).

Analysis of the polyisoprene indicates a unimodal distribution, with a median molecular weight $\left(\mathrm{M}_{n}\right)$ of 192 and a weighted average $\left(\mathrm{M}_{\mathrm{W}}\right)$ of 571 . The polydispersion index
$\left(\mathrm{M}_{\mathrm{w}} / \mathrm{M}_{\mathrm{n}}\right)$ was 2.97, a value comparable to that of natural rubber from Hevea brasiliensis (AikHwee et al., 1993).

The infrared spectrum showed bands between 3036 and $2726 \mathrm{~cm}^{-1}$, corresponding to axial deformations of the methyl, methylene and methine $\mathrm{C}-\mathrm{H}$ groups. The absorption at $1664 \mathrm{~cm}^{-1}$ was attributed to the axial deformation of the double bond of the cispolyisoprene. The absorptions at $1376 \mathrm{~cm}^{-1}$ and $1216 \mathrm{~cm}^{-1}$ corresponded to the symmetrical angular deformations of the methyl group and the asymmetric out-of-plane deformation of the methylene group, in accordance with other data for cis-polyisoprene (Aik-Hwee et al., 1993; Richardson et al., 1953). The ${ }^{1}$ H NMR spectrum showed signals at 1.68 ppm, attributed to methyl group hydrogens, $2.05 \mathrm{ppm}$, corresponding to the methylene hydrogens, and $5.13 \mathrm{ppm}$, for the vinylic hydrogens. The ${ }^{13} \mathrm{C}$ NMR spectrum showed signals at $23.3 \mathrm{ppm}$ (methyl carbon), $26.3 \mathrm{ppm}$ (methylene group adjacent to an unsubstituted olefinic carbon); $32.2 \mathrm{ppm}$ (methylene group adjacent to a substituted olefinic carbon), 125.0 ppm (olefinic carbon linked to a methyl group) and $135.1 \mathrm{ppm}$ (olefinic carbon). Comparison of the IR spectra, ${ }^{1} \mathrm{H}$ and ${ }^{13} \mathrm{C}$ NMR of the polymer, with spectra described in the literature, shows that this $H$. sucuuba latex polymer is cis-polyisoprene (Aik-Hwee et al., 1993; Richardson et al., 1953; Tanaka et al., 1995).

\section{CONCLUSION}

The polymer in the latex was identified as cis-polyisoprene, whose occurrence in many plants accompanies that of other isoprene based secondary products, such as triterpenes and their esters. The most abundant elements, 
calcium and magnesium, can be considered as contributors to the antiphlogistic and antitumoral medicinal properties attributed by popular use to the latex.

\section{ACKNOWLEDGEMENTS}

The authors thank FUJB and PRONEX for financial aid, Dr. Benjamin Gilbert for a critical review of the manuscript and Mr. Raimundo S. Carneiro for the plant material collected. JRAS thanks CAPES for a fellowship during the development of the study and the Botanical Institute - SP for the carbohydrate analyses.

\section{LITERATURE CITED}

Agrawal, P.K. 1992. NMR spectroscopy in the structural elucidation of oligosaccharides and glycosides. Phytochemistry, 31:3307-3330.

Aik-Hwee, E.; Tanaka, Y. 1993. Structure of natural rubber. Trends in Polymer Science, 493-513.

Corradini, C.; Canali, G.; Cavazza, A.; Delfino, D.; Teti, G. 1998. Compositional analysis of the major capsular polysaccharides of Cryptococcus neoformans by high performance anion-exchange chromatography with pulsed amperometric detection (HPAEC-PAD). J. Liq. Chromatogr R.T., 21:941-951.

Corrêa, M.P. 1975. Dicionário das plantas úteis do Brasil e das exóticas cultivadas. Imprensa Nacional, vol VI, Ministério da Agricultura, Rio de Janeiro, Brasil, pp. 154 155.
Dubois, M.; Gilles, A.; Hamilton, J.K.; Rebers, P.A.; Smith, S. 1956. Colorimetric method for determination of sugars and related substances. Anal. Chem., 28:350-355.

Elisabetsky, E.; Castilhos, C. 1990. Plants used as analgesics by Amazonian caboclos as basis for selecting plants for investigation. Int. J. Crude Drug Res, 28:309-320.

Hamburger, M.O.; Cordell, G.A.; Ruangrungsi, N. 1991. Tradicional medicinal plants of Thailand. XVII. Biologically active constituents of Plumeria rubra. J. Ethnopharmacol., 33:289-292.

Larson, R.A. 1995. The antioxidants of higher plants. Phytochemistry, 27:969-978.

Lipkin, M.; Newmark, H. 1995. Calcium and the prevention of colon cancer. J. Cell. Biochem., 22:65-73.

Miranda, A.L.P.; Silva, J.R.A.; Rezende, C.M.; Neves, J.S.; Parrini, S.C.; Pinheiro, M.L.B.; Cordeiro, M.C.; Tamborim, E.; Pinto, A.C. 2000. Anti-inflammatory and analgesic activities of extracts from Himatanthus sucuuba (Spruce) Woodson. Planta Med., 66:284-286.

Moir, G.F.J. 1959. Ultracentrifugation and staining of Hevea latex. Nature, 184:16261628.

Perdue, G.P.; Blomster, R.N. 1978. South American plants. III: isolation of fulvoplumerin from Himatanthus sucuuba (M. Arg.) Woodson (Apocynaceae). $J$. Pharm. Sci., 67:1322-1323.

Pereira, C.E.B.; Felcman, J. 1998. Correlation between five minerals and healing effect of Brazilian medicinal plants. Biol. Trace Elem. Res., 65:251-259. 
Richardson, W.A.; Sacher, A. 1953. Infrared examination of various polyisoprenes. $J$. Polym. Sci. Part A: Polym. Chem., 10:353370.

Silva, M.S. 1997. Relação entre os teores de elementos traço e as propriedades terapêuticas de algumas plantas da região amazônica. Dissertação de mestrado, Pontifícia Universidade Católica do Rio de Janeiro, Rio de Janeiro, 73 p.

Silva, J.R.A.; Rezende, C.M.; Pinto, A.C.; Pinheiro, M.L.B.; Cordeiro, M.C.; Tamborim, E.; Young, C.M.; Bolzani, V.S. 1998. Ésteres triterpênicos de Himatanthus sucuuba (Spruce) Woodson. Quím. Nova, 21:702-704.

Tanaka, Y. 1989. Structure and biosynthesis mechanism of natural polyisoprene. Prog. Polym. Sci., 14:339-371.

Tanaka, Y.; Kawahara, S.; Aik-Hwee, E.; Shiba, K.; Ohya, N. 1995. Initiation of biosyntheses in cis polyisoprenes. Phytochemistry, 39:779-784.

van den Berg, M.A. 1984. Ver-O-Peso: The ethnobotany of an Amazonian market. In: Prance, G.T.; Kallunki, J.A. (Eds). Advances in Economic Botany 1, Ethnobotany in the Neotropics. New York Botanical Garden, Bronx, New York. pp.140-149.

Vilegas, J.H.Y.; Hachich, E.M.; Garcia, M.; Brasileiro, A.; Carneiro, M.A.G.; Campos, V.L.B. 1992. Antifungal compounds from Apocynaceae species. Rev. Latinoamer. Quím., 23:44-45.

Wood, R.J.; Suter, P.M.; Russel, R.M. 1995. Mineral requirements of elderly people. Am. J. Clin. Nutr., 62:493-505.

Submetido à publicação: 14/08/2001

Aceito: $07 / 10 / 2002$ 